\title{
Autosomal recessive limb-girdle muscular dystrophy type 2P
}

INSERM

\section{Source}

INSERM. (1999). Orphanet: an online rare disease and orphan drug data base. Autosomal recessive limb-girdle muscular dystrophy type 2P. ORPHA:280333

Autosomal recessive limb-girdle muscular dystrophy type 2P (LGMD2P) is a form of limbgirdle muscular dystrophy characterized by slowly-progressive, mainly proximal, muscle weakness presenting in early childhood (with difficulties walking and climbing stairs) and mild to severe intellectual disability. Additional manifestations reported include microcephaly, mild increase in thigh or calf muscles, and contractures of the ankles. 